\title{
Debt to Equity Ratio (DER) dan Return On Asset (ROA) untuk Meningkatkan Harga Saham
}

\author{
S. Kurniasih ${ }^{1}$, A. Surachim \\ Universitas Pendidikan Indonesia \\ sarah.kurniasih@student.upi.edu
}

\begin{abstract}
The purpose of this study is to inform impact Debt to Equity Ratio (DER) and Return On Equity (ROA) to Stock Price. The research does in range of time less of one year, in order to research design that used is time interest earned. This research that used to sampling technique time series The research is used descriptive approach and verificative with explanatory research and data analysis technique that used multiple linear regression. The results of this study is Debt to Equity Ratio (DER) and Return On Asset (ROA) has impact is significant to Stock Price. The differences is decided in independent variable object, and reaserch method. Population and research sample, research period, measure instrument and research result, and source of theory and international journal and international book.
\end{abstract}

\footnotetext{
ABSTRAK

Tujuan dari penelitian ini untuk mengetahui pengaruh Debt to Equity Ratio (DER) dan Return On Equity (ROA) terhadap Harga Saham. Penelitian ini dilakukan terhadap sample tanpa random tetapi dengan menggunakan data historis, maka desain penelitian ini menggunakan time series design. Penelitian ini menggunakan pendekatan deskriptif dan verifikatif dengan metode explanatory research serta teknik analisis data menggunakakn regresi linear berganda. Hasil penelitian ini adalah Debt to Equity Ratio (DER) dan Return on Asset (ROA) berpengaruh terhadap Harga Saham. Perbedaan ditentukan dalam variabel independen, objek dan metode penelitian, populasi dan sampel penelitian, periode penelitian, alat ukur dan hasil penelitian,, serta sumber teori dan jurnal asing dan buku asing serta hasil penelitian.
}

\author{
ARTICLE INFO: \\ Article history: \\ Received 18 June 2018 \\ Revised 18 June 2018 \\ Accepted 19 June 2018 \\ Available online 3 September \\ 2018
}

Keywords:

Capital Structure; Debt to

Equity Ratio (DER),

Investor

Leverage,

Profitability,

Return On Asset (ROA),

Stock Price.

Stock Exchange

\section{Kata Kunci:}

Bursa Efek, Harga Saham, Investor; Leverage, Profitabilitas, Rasio Utang terhadap Ekuitas (DER), Return On Asset (ROA), Struktur Modal

\section{PENDAHULUAN}

Saham merupakan surat berharga sebagai bukti penyertaan atau pemilikan individu ataupun institusi dalam suatu perusahaan (Robert Ang, 2010) Sebelum melakukan investasi pada saham, calon investor harus memastikan bahwa investasi yang dilakukan adalah tepat. Artinya ia harus menilai dari berbagai alternatif yang akan mendatangkan pengembalian positif di masa 
yang akan datang, baik dalam bentuk dividen yaitu pengembalian atau penghasilan yang berdasarkan pada keuntungan yang diperoleh perusahaan berdasarkan saham yang dimiliki, maupun dalam bentuk capital gain yaitu kelebihan harga jual dari harga beli saham (Kim, Kim, \& An, 2015). Setiap perusahaan yang listing di Bursa Efek Indonesia atau go public pasti menerbitkan saham yang dapat dimiliki oleh setiap investor, tetapi harga saham sangatlah fluktuatif dan selalu berubah. Maka dari itu, investor harus pandai-pandai dalam menganalisis harga saham tersebut karena jika salah dalam menganalisis harga saham, maka investor akan mengalami kerugian sebelum berinvestasi (Cipto \& Fakhruddin, 2001:101).

Adanya lonjakan di pasar saham Cina yaitu Indeks utama Shanghai naik lebih dari dua kali lipat dalam 12 bulan sampai pertengahan tahun 2015. Dampak langsung turunnya harga saham di Cina kini yang menjadi kekhawatiran adalah apakah ini menjadi cerminan masalah perlambatan ekonomi yang lebih besar yang mendunia (Kim et al., 2015) Harga saham menjadi bgian penting dari keputusan investasi calon investor yang mendapat perhatian dari berbagai peneliti untuk dikaji secara mendalam (Bennet, 2010).

Penelitian mengenai harga saham terus mengalami perkembangan dan dikaji melalui banyak pendekatan. Perusahaan dapat melakukan perbaikan berkelanjutan untuk menciptakan keunggulan kompetitif dengan meningkatkan harga saham di dalam perusahaan (Magdalena, 2012) Pasar Modal di Indonesia mencakup berbagai jenis perusahaan berdasarkan bidang yang digeluti dengan membentuk beberapa klasifikasi berdasarkan sektor industri diantaranya terdapat industri pertanian, industri pertambangan, Industri dasar dan kimia, Aneka industri, industri barang kosumsi, properti dan real estate, transportasi dan infrastruktur, industri keuangan, dan industri perdagangan jasa dan investasi. Berdasarkan analisis industri, maka industri tambang batubara memasuki tahap ekspansi, dimana pemerintah terlihat sedang melakukan penggalakan untuk menggunakan batubara sebagai bahan bakar untuk mengurangi ketergantungan terhadap minyak bumi. Pernyataan tersebut berbanding terbalik dengan informasi yang dikeluarkan oleh Badan Pusat Statistik (BPS) yang mempublikasikan bahwa pertumbuhan ekonomi Indonesia sepanjang 2015 terjadi disemua sektor lapangan usaha kecuali industri pertambangan dan penggalian.

Berikut merupakan informasi mengenai lima saham yang sempat membuai pelaku pasar karena harga sahamnya naik dan turun signifikan dalam kurun waktu 2011-2013 dilansir dari liputan6.com diantaranya diurutan pertama dengan harga saham yang mengalami fluktuasi sangat signifikan yaitu PT Bumi Resources Minerals Tbk yang baru melakukan IPO pada saham-sahamnya di Bursa Efek Indonesia pada tahun 1990 dengan menerbitkan 10.000.000 saham dengan harga perlembar saham yaitu $\mathrm{Rp} 4.500,00$ tetapi semenjak 15 tahun terakhir, tercatat gejolak harga saham yang semakin menurun dan puncaknya pada tahun 2008 tercatat nilai saham PT Bumi Resources beradapada kisaran Rp 910/lembarnya, yang apada tahun sebelumnya berada pada nilai tertinggi yaitu Rp 6.000/lembarnya, hingga pada akhir tahun 2012 tercatat harga sahamny pada kisaran Rp 590/ lembarnya dan pada setiap tahunnya harga saham perusahaan tersebut menurun drastis hingga pada tahun 2015 kemarin nilai saham tersebut hanya seharga Rp 50 harga saham BUMI berada di level terendahnya disusul dengan PT Garda Tujuh Buana Tbk (GTBO), PT Krakatau Steel Tbk (KRAS), PT Bakrieland Development Tbk (ELTY), dan PT Garuda Indonesia Tbk (GIAA). Dengan dua perusahaan yang berasal dari industri pertambangan subsektor batubara.

Harga saham yang terus menerus mengalami penurunan akan berdampak pada minat dan keputusan investor untuk 
menanamkan hartanya untuk dijadikan sebagai modal pada perusahaan subsektor batubara yang terdaftar di BEI. Terjadinya perbedaan antara prediksi atau ekspektasi dengan kenyataan yang telah dihadapi membuat fenomena ini menarik untuk diteliti. Jika peramalan tersebut membuat para calon investor berbondong-bondong membeli saham atau mempertahankan saham yang saat ini mereka miliki karena melihat prospek kinerja perusahaan yang relatif akan naik, tetapi seiring dengan berjalannya waktu dilihat kinerja perusahaan yang kian menurun tentu akan membuat investor merugi. Harga saham yang kian terpuruk akan berdampak pula pada kepercayaan investor dalam menamkan hartanya untuk berinvestasi. Jika harga saham perusahaan emiten tidak kunjung meningkat, maka tidak akan ada investor yang akan berinvestasi pada perusahaan tersebut, ini berarti perusahaan akan mengalami kebangkrutan dikarenakan harga saham yang terpuruk dan harga saham yang terpuruk tersebut merupakan hal yang penting dalam sebuah perusahaan sehingga itulah yang menjadi masalah dalam penelitian ini.

Tujuan penelitian ini adalah: (1) memperoleh temuan mengenai gambaran Debt to Equity Ratio (DER), (2) memperoleh temuan mengenai gambaran Return On Asset (ROA), (3) memperoleh temuan mengenai Debt to Equity Ratio (DER) dan Return On Asset (ROA) terhadap harga saham.

\section{KAJIAN PUSTAKA}

Perusahaan selalu membutuhkan dana untuk menunjang kelancaran kegiatan operasinya dan menjaga kelangsungan hidupnya dalam persaingan bisnis yang semakin ketat karenanya dibutuhkannya sumber modal untuk menunjang operasional perusahaan (Husnan Pudjiastuti, 1996) . Struktur modal adalah pembelanjaan permanen dimana mencerminkan pengimbangan antar hutang jangka panjang dan modal sendiri. Modal sendiri adalah modal yang berasal dari perusahaan itu sendiri (cadangan laba) atau berasal dari mengambil bagian, peserta, atau pemilik (modal saham, modal peserta, dan lain-lain) (Riyanto, 2008:22). Untuk mendapatkan modal usaha, perusahaan akan berupaya mencari sumbersumber dana yang dapat menjadi penunjang untuk operasional perusahaanya. Salah satu cara untuk mendapatkan modal bagi perusahaan yaitu dengan menerbitkan saham perusahaan untuk menarik investor agar menanamkan hartanya di perusahaan berdasarkan harga saham yang ditetapkan.

Harga saham merupakan harga atau nilai uang yang bersedia dikeluarkan untuk memperoleh atas suatu saham (Widoatmojo, 2012:45). Darmadji \& Fakhruddin, (2012:12) juga mengemukakan bahwa harga saham merupakan Harga yang terjadi di bursa pada waktu tertentu. Harga saham bisa berubah naik atau pun turun dalam hitungan waktu yang begitu cepat. Harga saham dapat berubah dalam hitungan menit bahkan dapat berubah dalam hitungan detik. Hal tersebut dimungkinkan karena tergantung dengan permintaan dan penawaran antara pembeli saham dengan penjual saham. Harga saham merupakan nilai suatu perusahaan yang dijadikan ukuran keberhasilan perusahaan tersebut oleh investor dan calon investor (Surachim, Kusuma, \& Tanuatmodjo, n.d.)

Harga saham menentukan kekayaan pemegang saham. Maksimalisasi kekayaan pemegang saham diterjemahkan menjadi memaksimalkan harga saham perusahaan. Harga saham pada satu waktu tertentu akan bergantung pada arus kas yang diharapkan diterima dimasa depan oleh investor rata-rata jika investor tersebut membeli saham (Brigham dan Huston, 2010:7). (Darmadji, 2011). Manaje Jr, (2012) menyatakan: "A share price is the price of a single share of a company's stock. Share prices in a publicly traded company are determined by market supply and demand". 
Dalam menentukan harga saham, harus memperhatikan hukum penawaran dan permintaan.Apabila permintaan akan saham lebih besar dari penawaran saham, maka harga saham akan mengalami kenaikan. Begitu pula sebaliknya, jika permintaan akan saham lebih kecil dari penawaran, maka akan menyebabkan penurunan harga saham. Harga saham akan stabil dan berada pada titik ekuilibrium jika antara permintaan dan penawaran terjadi keseimbangan (Brigham, da Houston 2006). Harga saham dapat dikatakan sebagai indikator keberhasilan pengelolaan perusahaan, dimana kekuatan pasar ditunjukkan dengan terjadinya transaksi perdagangan saham perusahaan dipasar modal (Setyorini dkk, 2016:6).

Terbentuknya harga saham dibentuk berdasarkan suatu dasar tertentu. Saat perusahaan didirikan, harga sahamnya tercermin dari jumlah modal sendiri (equity) per sahamnya. Setelah perusahaan berdiri, kemudian beroperasi dan berkembang baik, tentunya perusahaan mulai memberikan hasil yaitu antara lain berupa deviden tunai. Jika perusahaan berkembang pesat, maka laba dan deviden juga akan meningkat, sehingga nilai perusahaan akan meningkat (Fitriah \& Frans Sudirjo, 2016:3) . Tinggi rendahnya harga saham ini ditentukan oleh permintaan dan penawaran tersebut di pasar modal. Harga saham terbentuk dari proses demand dan supply yang terjadi di bursa. Jika supply lebih besar daripada demand, maka akan menyebabkan pergerakan harga yang menurun. Dan demikian juga sebaliknya, jika supply lebih besar dari pada demand, maka harga akan bergerak naik (Vice Law Ren Sia \& Lau Tjun Tjun, 2011).(Brigham, dan Houston (2010:152) berpendapat bahwa suatu faktor yang dapat mempengaruhi pergerakan harga saham adalah proporsi utang perusahaan terhadap ekuitas. Para investor tentu menginginkan prospek tingkat pengembalian yang tinggi, namun merkea enggan untuk menghadapi risiko, karena investor itu lebih tertarik kepada saham yang tidak terlalu banyak menanggung risiko dan risiko hutang yang tinggi

Siegel dan Shim dalam Fahmi, (2012:128) mendefinisikan Debt to Equity Ratio (DER) "Ukuran yang dipakai dalam menganalisis laporan keuangan untuk memperlihatkan besarnya jaminan yang tersedia untuk kreditor". DER merupakan rasio yang dapat menunjukkan hubungan pinjaman jangka panjang yang diberikan oleh kreditur dengan jumlah modal sendiri yang diberikan oleh pemilik perusahaan (Syamsudin, 2011:54).

Ariska Trisnandari (2015) menyatakan bahwa Debt to Equity Ratio (DER) dapat menunjukkan atau menggambarkan pengaruh terhadap banyak kondisi. Kaitannya dengan pihak investor, DER berpengaruh pada Dividen. Semakin tinggi tingkat Debt to Equity Ratio (DER), berarti komposisi hutang juga semakin tinggi, sehingga akan berakibat pada semakin rendahnya kemampuan perusahaan untuk membayarkan Dividend Payout Ratio (DPR) kepada pemegang saham, sehingga rasio pembayaran deviden semakin rendah. Debt to Equity Ratio akan mempengaruhi kinerja perusahaan dan menyebabkan apresiasi harga saham.

DER yang terlalu tinggi mempunyai dampak buruk terhadap kinerja perusahaan, karena tingkat utang yang semakin tinggi menandakan beban bunga perusahaan akan semakin besar dan mengurangi keuntungan. Sehingga makin besar utang (DER) cenderung menurunkan harga saham (Putri, 2012). Selain itu, hal yang dapat mempengaruhi harga saham yang beredar di pasar modal yaitu kinerja keuangan perusahaan terkait diantaranya rasio profitabilitas, likuiditas, dan leverage/ Deb to Equity Ratio (DER) (Safitri, Okky, 2015:2). Selain itu, faktor-faktor yang mempengaruhi harga saham diantaranya:aktivitas, 
solvabilitas, likuiditas, dan profitabilitas (Mahmud M Hanafi, dan Abdul Halim 2007:76) dan (Robert Ang, 2010:33).

Profitabilitas merupakan salah satu indikator kinerja keuangan perusahaan yang sering dijadikan bahan pertimbangan investor dalam mengambil keputusan berinvestasi. Rasio ini dimaksudkan untuk mengukur efektivitas manajemen dilihat dari laba yang dihasilkan terhadap penjualan dan investasi. Menurut Suad Husnan dan Enny Pudjiastuti (2007:317).

Deitiana (2011), menyatakan bahwa "Tanpa profit, perushaan tidak dapat menarik sumber modal eksternal untuk menginvestasikan dananya pada perusahaan". Profitabilitas yang tinggi menunjukkan prospek perusahaan yang baik sehingga investor akan merespon positif sinyal tersebut dan nilai perusahaan tersebut. Seperti yang dikatakan oleh Abdul Halim (2003:12) "Fluktuasi harga saham ditentukan oleh kemampuan perusahaan dalam memperoleh laba. Apabila laba yang diperoleh perusahaan relative tinggi, maka kemungkinan besar bahwa dividen yang dibayarkan juga relatif tinggi. Apabila dividen yang dibayarkan relatif tinggi, maka akan berimbas pada harga saham dibursa, dan investor akan tertarik untuk membelinya. Akibatnya, permintaan akan saham tersebut menjadi meningkat, sehingga akhirnya harganya juga meningkat". Salah satu rasio untuk mengukur kemampuan perusahaan dalam memperoleh profit adalah ROA (Return On Asset). ROA (Return On Asset) merupakan rasio yang membandingkan laba bersih yang diterima oleh perusahaan dengan aktiva yang dimiliki perusahaan. Semakin besar ROA maka akan semakin baik, hal tersebut berarti bank dapat memanfaatkan aktiva yang dimiliki untuk dijadikan profit (Surachim, 2009)

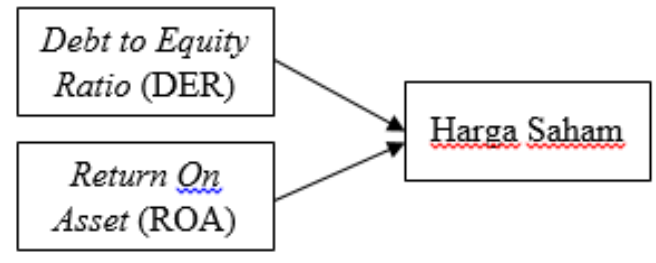

\section{Gambar 1. Paradigma Penelitian}

\section{METODEPENELITIAN}

Penelitian ini dilakukan untuk mengetahui pengaruh Debt to Equity Ratio (DER) dan Return On Asset (ROA) terhadap harga saham. Variabel bebal (independent variable) yang terdapat pada penelitian ini yaitu Debt to Equity Ratio (DER) dengan indikator total utang dan total modal dan Return On Asset (ROA) dengan indikator laba bersih dan total asset . sedangkan variabel terikat (dependent variable) pada penelitian ini yaitu harga saham dengan indikator laba bersih (Net income) dan jumlah saham beredar.

Penelitian ini dilakukan pada PT Bumi Resources Tbk. Desain penelitian yang digunakan yaitu Time Series dengan jenis penelitian deskriptid dan verifikatif. Berdasarkan jenis penelitian tersebut, maka metode yang digunakan dalam penelitian ini adalah explanatory research yang bertujuan untuk menguji hipotesis antara variabelvariabel bebas degan variabel terikat. teknik pengumpulan data yang digunakan adalah studi kepustakaan dan dokumentasi.

\section{HASIL DAN PEMBAHASAN}

Berdasarkan hasil perhitungan menggunakan regresi linear berganda antara pengaruh Debt to Equity Ratio (DER) terhadap harga saham sebesar 20,940 dan pengaruh Return On Asset (ROA) terhadap harga saham sebesar 10747,273.

Uji hipotesis dalam penelitian ini adalah dengan menggunakakan uji $F$ dan Uji t. Berdasarkan hasil uji t untuk menguji hipotesis parsial diperoleh nilai thitung sebesar 2,172 untuk DER dan 10,964 untuk ROA. Dengan tingkat signifikansi $\alpha=0,05$ diperoleh $\mathrm{t}_{\text {tabel }}$ sebesar 1,75305. Sehingga hasil $t_{\text {hitung }}>t_{\text {tabel }}$ 
untuk DER dan ROA. Maka dapat diambil keputusan bahwa $\mathrm{H}_{0}$ ditolak dan $\mathrm{H}_{\mathrm{a}}$ diterima.

Hal ini berarti terdapat pengaruh dari Debt to Equity Ratio (DER) terhadap harga saham. Sesuai dengan hasil penelitian yang dilakukan oleh Alep Pradipta Abimantara (2013), Idawati \& Aditio Wahyudi (2015), dan Surya Sarjito, And Harlandy Hasbi (2011) yang menyatakan bahwa Debt to Equity Ratio (DER) berpengaruh terhadap harga saham. Sehingga dapat dikatakan bahwa semakin tinggi nilai Debt to Equity Ratio (DER) akan semakin besar kemungkinan harga saham yang meningkat. Debt to Equity Ratio (DER) yang tinggi mengindikasikan bahwa kegiatan operasional perusahaan banyak didanai oleh dana dari pihak luar perusahaan (utang) yang kemungkinan dapat membantu prospek kinerja perusahaan dalam maksimalisasi profit sehingga nilai perusahaan meningkat dan investor lebih tertarik untuk memiliki saham tersebut dan menjadikan permintaan terhadap saham meningkat sehingga akan berimbas pada naiknya harga saham perusahaan di pasar.

Terdapat pengaruh yang signifikan dari Return On Asset (ROA) terhadap harga saham. Hal tersebut sesuai dengan penelitian yang dilakukan oleh Susanti, Dwi and Misdiyono (2011), Riantani, Suskim, Tantra Hartaya (2011), dan Atika Jauharia Hatta dan Bambang, (2012) yang menyatakan bahwa Return On Asset (ROA) berpengaruh terhadap harga saham. Sehingga dapat dikatakan bahwa semakin tinggi nilai Return On Asset (ROA) akan semakin tinggi pula harga saham pada perusahaan.

Hasil penelitian secara empiris menunjukkan bahwa Debt to Equity Ratio (DER) memiliki pengaruh terhadap harga saham PT Bumi Resources Tbk sehingga hipotesis yang diajukan penulis yaitu bahwa Debt to Equity Ratio (DER) berpengaruh terhadap harga saham sesuai dan dapat diterima. Berikut adalah hasil penelitian empiris kondisi Debt to Equity Ratio (DER) terhadap harga saham.
Kondisi Debt to Equity Ratio (DER) dan harga saham pada PT Bumi Resources Tbk periode 2010-2015 yaitu mengalami fluktuasi dan cenderung menurun. Debt to Equity (DER) PT Bumi Resources Tbk pada tahun 2010 berada di 3,95\% diikuti dengan harga saham di angka Rp 2.376,14. Perusahaan mengalami peningkatan Debt to Equity Ratio (DER) sebesar 0,11 menjadi 4,06 dan juga diikuti dengan harga saham yang menguat menjadi Rp 2.652,65. Pada tahun 2012 DER PT Bumi Resources Tbk mengalami kenaikan kembali melebihi kenaikan di tahun sebelumnya sebesar 1,2 menjadi 5,26\% namun, kali ini tidak terjadi kenaikan pula terhadap harga saham yang menurun menjadi Rp 2.516,21 dan pada tahun 2013 terjadi kenaikan Debt to Equity Ratio (DER) yang melesat hingga mencapai 17,75 dan kondisi ini diikuti dengan harga saham yang kian anjlok sebesar Rp 1.836,21 menjadi Rp 680,00. Harga saham PT Bumi Resources Tbk kian merosot di harga Rp 307,00 dan di akhir tahun 2015 mencapai harga terendahnya di harga Rp 50,00 seiring denga kian meroketnya nilai Debt to Equity Ratio (DER) hingga mencapai nilai 24,12 dan di tahun 2015 nilai DER perusahaan sampai pada nilai negatif di angka $-9,87$

Hasil penelitian secara empiris juga menunjukkan bahwa profitabilitas yang diukur dengan Return On Asset (ROA) memiliki pengaruh terhadap harga saham pada PT Bumi Resources sehingga hipotesis yang diajukan penulis yaitu bahwa profitabilitas yang diukur dengan Return On Asset (ROA) berpengaruh terhadap harga saham sesuai dan dapat diterima. Berikut adalah hasil penelitian empiris kondisi Return On Asset (ROA) terhadap harga saham.

Kondisi Rasio Return On Asset (ROA) dan harga saham pada PT Bumi Resources Tbk periode 2010-2015 yaitu mengalami fluktuasi dan cenderung menurun. Return On Asset 
(ROA) PT Bumi Resources Tbk pada tahun 2010 berada di $0,09 \%$ diikuti dengan harga saham di angka Rp 2.376,14. Perusahaan mengalami peningkatan Return On Asset (ROA) sebesar $0,04 \%$ menjadi 0,13 dan juga diikuti dengan harga saham yang menguat menjadi Rp 2.652,65. Pada tahun 2012 ROA PT Bumi Resources Tbk mengalami kenaikan kembali sebesar $0,02 \%$ menjadi 0,15 namun kali ini tidak diikuti dengan harga saham yang naik, pada tahun 2012 ini harga saham perusahaan justru mengalami penurunan menjadi Rp 2.516,21 dan anjlok pada tahun 2013 sebesar Rp 1.836,21 menjadi Rp 680,00 terus menurun secara berkelanjutan ditahun berikutnya diharga hingga tahun 2015 harga saham di PT Bumi Resources Tbk berada pada harga Rp 50,00. Sementara itu nilai Return On Asset (ROA) PT Bumi Resources Tbk juga mengalami penurunan yang tinggi pula di tahun 2013 hingga menembus angka negative diangka $-0,08$ yang artinya bahwa perusahaan mencerminkan kerugian. Ditahun 2014 kerugian perusahaan semakin besar menjadi $0,11 \%$ dan di tahun berikutnya PT Bumi Resources masih dalam kondisi merugi meski perusahaan dapat mengurangi tingkat kerugian mereka menjadi -0,07 untuk laba dari efesiensi perusahaan menggunakan asset yang dimiliki.

\section{KESIMPULAN DAN SARAN}

Berdasarkan hasil penelitian yang telah dilakukan menggunakan analisis deskriptif dan verifikatif dengan menggunakan analisis linear berganda dapat diambil kesimpulan yaitu hasil penelitian menyattakan bahwa Debt to Equity Ratio (DER) dan Return On Asset (ROA) secara parsial berpengaruh terhadap harga saham. Return On Asset berpengaruh positif signifikan terhadap harga saham PT Bumi Resources Tbk sedangkan Debt to Equity Ratio (DER) berpengaruh positif tidak signifikan terhadap harga saham PT Bumi Resources Tbk pada periode 2010-2015.

Adanya penelitian ini diharapkan dapat membantu peneliti berikutnya dalam melakukan penelitian mengenai Debt to Equity Ratio (DER), Retun On Asset (ROA), dan harga saham. 


\section{DAFTAR PUSTAKA}

Abdul, H. (2003). Pengaruh Dividend Per Share dan Earning Per Share Terhadap Harga Saham Pada Perusahan Go Public di Bursa Efek Indonesia. Skripsi Fakultas Ekonomi Medan Universitas Sumatera Utara., 3(1), 1-20.

Atika Jauharia Hatta dan Bambang. (2012). The Company Fundamental Factors And Systematic Risk In Increasing Stock Price. Journal of Economic, Business and Accountancy Ventura, 15(2), 245256.

Brigham, Eugene F. dan Gapenski, L. C. (2010). Financial Management:Theory and Practice. Florida: Harcourt College Publisher

Cipto, D., \& Fakhruddin, H. M. (2001). Pasar Modal di Indonesia (Vol. 32). Jakarta: Salemba Empat.

Darmadji \& Fakhruddin. (2011). Pasar Modal di Indonesia. Jakarta: Salemba empat.

Fahmi, I. (2012). Analisis Laporan Keuangan. Bandung: Alfabeta.

Hanafi, M. H. dan A. H. (2007). Analisis Laporan Keuangan, edisi 3 (Vol. 26). Yogyakarta: UPP STIM YKPN.

Husnan. (1996). Manajemen Keuangan Teori dan Penerapan (Vol. 1). Yogyakarta: BPFE.

Husnan, S. dan E. P. (2006). Dasar Dasar Manajemen Keuagan. Yogyakarta: UPP STIM YKPN.

Idawati, W. dan A. W. (2015). Effect of Earning Per Shares (EPS) and Return On Assets (ROA) against Share Price on Coal
Mining Company Listed in Indonesia Stock Exchange. Jurnal of Resources and Development, 07(79), 79-91.

Jr, M. (2012). Determinants Of Stockprices In Financial Sectors Companies In Bangladesh- A Study On Dhaka Stock Exchabge (DSE). Journal Of Contemporary Research In Business, 05.

Kim, H., Kim, W. . yoo, \& An, J. . (2015). The Effect of Consumer-Based Brand Equity On Firms Financial Performance. Consumer Marketing (Vol. 20). Bandung: Urban Press. http://doi.org/10.1108/174656809109942 09

Magdalena. (2009). Valuasi Saham pada Industry Tambang Batubara dengan menggunakan Analisis Free Cash Flow to Equity, Abnormal Earning, dan Relative Valuation. IJOP, 01(67), 97119.

Pradipta, A. B. (2013). Pengaruh Price to Earning Ratio, Debt to Equity Ratio, Return On Asset dan Price to Book Value terhadap Harga Pasar Saham. Jurnal Bisnis Dan Akuntansi, 11.

Putri. (2012). Faktor-Faktor yang mempengaruhi Return On Assets (ROA) Pada Bank Swasta Nasional di Indonesia Periode 2006-2010. Jurnal Riset Dan Informasi Ekonomi, 03.

Riantani, Suskim, Tantra Hartaya, A. H. (2011). Analysis of Debt to Equity Ratio and Return onAssets and its Effect to Closing Price of theMining Industry listed in BEI, 13(2).

Riyanto, B. (2008). Dasar-dasar Pembelanjaan Perusahaan (Vol. 10). yogyakarta: GPFE. 
Robert Ang. (2010). Buku Pintar Pasar Modal Indonesia. Keuangan (Vol. 2). Jakarta: Media Staff Indonesia.

Safitri, Okky, D. (2015). Analisis Pengaruh Profitabilitas, Likuiditas, dan Leverage Terhadap Return Saham Pada Perusahaan Manufaktur Yang Terdaftar di BEI Tahun 2009-2013, 3(1), 1-9.

Setyorini. (2016). Pengaruh Dividend Per Share dan Earning Per Share Terhadap Harga Saham Pada Perusahaan Industri Barang Konsumsi yang Terdaftar di BEI. E-Journal S1 Ak Universitas Pendidikan Ganesha Jurusan Akuntansi Program S1, 02(01), 75-123.

Sudirjo, F. \& F. (2016). Analisis Pengaruh Dividend Per Share, Debt to Equity Ratio, dan Earning Per Share terhadap Harga Saham pada Perusahaan Go Public di Bursa Efek Indonesia. Jurnal Riset Dan Akuntansi Going Concern FE UNSRAT, 05(02).

Surachim, A. (2009). Pengaruh Penyaluran Kredit (LOAN) Terhadap Profitabilitas (Studi Kasus pada Laporan Keuangan PT Bank Mega Tbk ), 40-48.I

Surachim, A., Kusuma, P., \& Tanuatmodjo, H. (n.d.). Dampak tingkat profitabilitas dan nilai pasar pada pergerakan harga saham pt. prasidha aneka niaga tbk, 1-7.

Surya Sarjito. (2011). Jurnal Pengaruh Struktur Dana Pihak Ketiga Terhadap Tingkat Rentabilitas(Studi Kasus pada Bank Nasional Indonesia dan Bank Permata. Jurnal Universitas Dan Bisnis Indonesia. ISSN, O8(21), 2085-7995.

Susanti, Dwi and Misdiyono, M. (2011). Financial Performance Analysis To Stock's Price Of The Metal
Manufacturing Sector In Indonesia Stock Exchange. Skripsi Program Studi Akuntansi., 09(13), 1-15.

Syamsudin. (2011). Pengaruh Faktor Fundamental Internal terhadap Harga Saham (Studi pada Saham LQ45 yang listing di BEI tahun 2006-2010). IJJOP, 08(14), 1-15.

Trisnandari, A. (2015). Analisis Pengaruh Rasio Profitabilitas terhadap Harga Saham pada Perusahaan Subsektor Semen yang terdaftar di BEI. Jurnal Akuntansi UNESA. Http://ejournal.unesa.ac.id, 12(04), 4753.

Vice Law Ren Sia \& Lau Tjun Tjun. (2011). determinants of share in india. journal of emerging trends in economics and management sciences. JETEMS, 02(02), 124-130.

Widoatmojo. (2013). Pengaruh Kinerja Keuangan Terhadap Harga Saham Pada Perusahaan Mining And Mining Service Di Bursa Efek Indonesia (BEI). Jurnal Aplikasi Bisnis, 03(01) 